\title{
Population Structure of Phalloceros caudimaculatus (Hensel, 1868) (Cyprinodontiformes, Poeciliidae) Collected in a Brook in Guarapuava, PR
}

\author{
Luciano Lazzarini Wolff ${ }^{1}$, Ericsson Ricardo Hreciuk ${ }^{1}$, Douglas Viana ${ }^{1}$, Tânia Zaleski ${ }^{2}$ and \\ Lucélia Donatti*1 \\ ${ }^{1}$ Universidade Federal do Paraná; Departamento de Biologia Celular; C.P. 19031; 81531-970; Curitiba - PR - \\ Brasil. ${ }^{2}$ Faculdade de Ciências Biomédicas de Cacoal;Rondônia - Brasil
}

\begin{abstract}
The population structure of Phalloceros caudimaculatus was studied in a brook (sites $A$ and B) existing in the CEDETEG - Guarapuava/PR. Fourteen length classes of $3 \mathrm{~mm}$ amplitude were defined for P. caudimaculatus. The widest length amplitude and the average and maximum sizes were observed in females. Females were significantly more predominant in the whole sample and more frequent in all length classes. The sexual proportion data, showed that the number of females was superior to that of males throughout most of the year. Young occurrence peaks were registered in November and March. Pregnant females were present from March to April, from July to August and in January, characterizing the reproductive season. At sampling site A, a higher occurrence of pregnant females and young was observed.
\end{abstract}

Key words: Fish; ecology; fresh-water

\section{INTRODUCTION}

Many authors have studied the biological aspects of the specific fauna of hydric systems of the state of Paraná (Agostinho, 1985, 1993; Wosiacki, 1990; Wosiaki and Cury, 1990; Fugi and Hahn, 1991; Gealh-Escobar, 1991; Dellome Filho, 1992; Góes de Moraes, 1995; Aranha et al., 1998; Grando Jr., 1999; Takeuti et al., 1990, Grando, 2000). Menezes (1972) and Bohlke et al. (1978) stressed the importance of comprehensive studies on the composition and the biology of the ichthyofauna existing in the Brazilian rivers and brooks. They emphasized that fishes existing in smaller rivers remained virtually unknown. Menezes (1994) reported that very few coverage studies on fish communities and populations in this ecosystem have been carried out. Thus, knowledge variations in species biology in their distribution area contribute to the detailed ecology. In many aspects the strategies of life of some species could the by interpretated by population structure analysis. The understanding of factors that could react to a community, depends on the knowledge of population structure, especially in the dominant species.

Phalloceros caudimaculatus (Hensel, 1868) is the only species of the genus Phalloceros (Eigenmann, 1907). Formerly described as belonging to the genus Girardinus, it was cited later on by Eigenmann (1894) in the genus Poecilia as $P$. caudimaculata. Afterwards,

\footnotetext{
${ }^{*}$ Author for correspondence
} 
Eigenmann (1907) described the genus Phalloceros, where he finally placed the species. Ihering (1931) characterized it as viviparous. It is omnivorous tending to herbivory, feeding mainly on algae (Sabino and Castro, 1990). As the case with other Poeciliidae, secondary modifications occur to the male anterior anal fin rays, which turn into a gonopodial system for the transferal of sperm into the female urogenital system (Rosen and Bailey, 1963).

The geographical distribution of this species in Brazil known so far includes areas of the state of Rio Grande do Sul (Hensel, 1868), of the state of Rio de Janeiro (Henn, 1916), the south of the state of Espírito Santo (Ihering, 1931; Rosen and Bailey, 1963) and the state of Bahia (Lulling, 1976; Arnold, 1989). In the state of São Paulo, its distribution includes the Paraíba River, all the other Atlantic slope rivers and the entire Tietê River (Ihering, 1931). Besides, specimens deposited in collections confirmed its occurrence in the state of Minas Gerais (Barros, 1995).

The present work aimed at providing some information regarding the population structure of $P$. caudimaculatus. The relationship between total length and total weight, the composition according to size, the frequency of young and adults, the sexual proportion and the frequency of pregnant and non-pregnant females were analyzed.

\section{METHODS}

Specimens of $P$. caudimaculatus were collected in a brook located in the campus of the CEDETEG Center for the Educational and Technological Development of Guarapuava. The CEDETEG, having an area of 46 alqueires, is situated in the Cascavel neighborhood in the city of Guarapuava, in the Centre-West region of the state of Paraná. It has a low-lying area dominated by wetlands, where several animals (such as birds, fishes and amphibians) and plants (such as water hyacinths and bushes) are found. A brook that is $0.8 \mathrm{~m}$ deep and 1.3 to $2 \mathrm{~m}$ wide runs along these wetlands. This brook is an affluent of Arroio do Carro Quebrado River, that ends at Cascavel River $\left(25^{\circ}\right.$ $18^{\prime} \mathrm{S}$ e $51^{\circ} 25^{\prime} \mathrm{W}$ ), pertain to an Iguaçu River Hydrographic Bay. This area was chosen for the sampling of fish.

Samplings were made at two sites of these wetlands, designated as A and B. Sampling site A was located in the midst of the wetlands and characterized by the presence of stagnant waters and abundant aquatic and marginal vegetation; sampling site B was located at the mouth of the brook, where it entered the wetlands, and characterized by the presence of running waters.

The specimens were obtained through monthly systematic samplings from March 2002 to February 2003. The specimens were obtained using a small sieve to catch fisheries $(45 \mathrm{~cm}$ of diameter). The sieve pass to collection area about 15 ways and the effort of amostral collection was the same in all the collections.

In the laboratory, the samples were measured for total lengths (TL) and weighed (TW). Sex was determined by the presence, or not of gonopodium. Specimens presenting no evidence of gonopodium development, or of reproductive activity were classified as young. Females were macroscopically classified according to the sexual maturation state. The females that were identified as pregnant presented a round-shaped ventral region, while the females which were held as non-pregnant did not. In case of doubt, a ventral incision was made, so that the presence or absence of developing embryos could be observed.

The population structure at sampling sites A and B was analyzed, month by month and as a whole, as to the frequency of young and adults and to the sexual proportion. The monthly relative frequency of pregnant and non-pregnant females was also analyzed. To analyze the composition according to size, specimens were grouped into size classes as defined by Sturges (Silva and Souza, 1987).

These results were statistically tested, the chisquare test $\left(\chi^{2}\right)$ being used whenever possible and assuming $\alpha=0.05$ to determine the statistical significance of the difference in the occurrence of young and adults, of males and females, and of pregnant and non-pregnant females, in relation to the months and sites. Equations for the lengthweight relationship were estimated for the sexes taken either together or separately. It was verified by this method whether the lines obtained for each sex would fit within the confidence interval of the line obtained for the data of all specimens. If they were, the lines for both sexes would be considered the same; if not, the lines for males and females would be considered distinct. 


\section{RESULTS}

There was a strong relationship between the total length and total weight shown for females. The equation $\mathrm{Wt}=0.0105 \times \mathrm{Lt}+3.1927$ explained $94.23 \%$ of the absence, or variance. For males, the relationship was rather weaker, and the equation $\mathrm{Wt}=0.0139 \mathrm{x} \mathrm{Lt}+2.8813$ explained $86.98 \%$ of the absence or variance obtained.

According to the total length, fourteen length classes of $3 \mathrm{~mm}$ amplitude were defined. $P$. caudimaculatus was found from $6.0-8.9 \mathrm{~mm}$ to 45.0-47.9mm classes (Table 01). Males were more frequent in the size classes 18.0-20.9 $\mathrm{mm}$ $(20.19 \%)$ and $21.0-23.9 \mathrm{~mm}(42.31 \%)$, the average total length being $22.3 \mathrm{~mm}(\mathrm{n}=208$; min: $9.6 \mathrm{~mm}$; max: $35.7 \mathrm{~mm}$ ). Females were more frequent in classes $21.0-23.9 \mathrm{~mm}(20.07 \%)$ and $24.0-26.9 \mathrm{~mm}$ $(16.49 \%)$, the average total length being $23.7 \mathrm{~mm}$ ( $\mathrm{n}=279$; min: $11.1 \mathrm{~mm}$; max: $45.8 \mathrm{~mm}$ ). Young individuals were more frequent in classes 6.0$8.9 \mathrm{~mm}(31.29 \%)$ and $9.0-11.9 \mathrm{~mm}(48.47 \%)$, the average total length being $10.1 \mathrm{~mm}(\mathrm{n}=163$; min: 6.5mm; max: $15.4 \mathrm{~mm}$ ).

Table 1 - Total number of length classes for females (F) and males (M) and for sites A and B of Phalloceros caudimaculatus.

\begin{tabular}{l|c|c|c|c}
\hline Length classes (mm) & \multicolumn{2}{|c|}{ F } & \multicolumn{2}{c}{ M } \\
\cline { 2 - 5 } & A & B & 0 & B \\
\hline $6,0-8,9$ & 0 & 0 & 2 & 0 \\
$9,0-11,9$ & 1 & 1 & 0 & 0 \\
$12,0-14,9$ & 6 & 4 & 4 & 3 \\
$15,0-17,9$ & 19 & 26 & 20 & 13 \\
$18,0-20,9$ & 19 & 26 & 47 & 22 \\
$21,0-23,9$ & 29 & 27 & 16 & 41 \\
$24,0-26,9$ & 27 & 19 & 5 & 19 \\
$27,0-29,9$ & 16 & 10 & 2 & 6 \\
$30,0-32,9$ & 13 & 6 & 0 & 7 \\
$33,0-35,9$ & 6 & 9 & 0 & 1 \\
$36,0-38,9$ & 7 & 4 & 0 & 0 \\
$39,0-41,9$ & 2 & 1 & 0 & 0 \\
$42,0-44,9$ & 0 & 0 & 0 & 0 \\
$45,0-47,9$ & 0 & 1 & 96 & 0 \\
\hline Total & 145 & 134 & 112 \\
\hline
\end{tabular}

The relative frequency analysis of occurrence of each length class at sampling sites $\mathrm{A}$ and $\mathrm{B}$, showed that the length classes $6.0-8.9 \mathrm{~mm}\left(\chi^{2}=\right.$ $33.76 ; \mathrm{p}<0.05 ;$ d.f. $=1)$ and $9.0-11.9 \mathrm{~mm} \quad\left(\chi^{2}=\right.$ 17.10; $\mathrm{p}<0.05$; d.f. $=1$ ) occurred predominantly at site $\mathrm{A}$, and that the length class $15.0-17.9 \mathrm{~mm}\left(\chi^{2}=\right.$ 4.50; $\mathrm{p}<0.05$; d.f. $=1$ ) occurred predominantly at site B. The other length classes showed no difference in frequency of occurrence between sites $\mathrm{A}$ and $\mathrm{B}$.

Despite sampling efforts, no specimens of $P$. caudimaculatus were collected in May and September. The proportion between adults and young differed significantly in all sampling months. By monthly analyzing the occurrence of young and adults, it was observed that the young were predominant in November $(32.52 \%)$ and
March $(25.77 \%)$ and the adults in June $(36.3 \%)$ and March (22.2\%) as show in Fig. 1a.

At site A, 359 individuals were collected, of which $37.23 \%$ were adults and $18 \%$ were young $\left(\chi^{2}=\right.$ $44.40 ; \mathrm{p}<0.0001 ;$ d.f. $=1)$. At site $\mathrm{B}, 291$ individuals were collected, $37.69 \%$ of them being adults and $7.08 \%$ of them being young $\left(\chi^{2}=\right.$ 149.39; $\mathrm{p}<0.0001$; d.f.=1). Site A had a greater number of young individuals than site $\mathrm{B}\left(\chi^{2}=\right.$ $31.99 ; \mathrm{p}<0.0001 ;$ d.f. $=1)$. There was no significant difference between the number of adult individuals at sites $\mathrm{A}$ and $\mathrm{B}\left(\chi^{2}=0.018 ; \mathrm{p}=0.89\right.$; d.f.= 1). The higher incidence of females and males occurred respectively in June $(34.17 \%$ and $39.23 \%)$ and March (21.94\% and $22.49 \%)$. In november (32.52\%) and March (25.77\%), a higher incidence of young individuals was observed (Fig. 
1a). Only in January, there was a difference in the monthly sexual proportion $\left(\chi^{2}=26.9 ; \mathrm{p}<0.0001\right.$; d.f.=1). In the other months, the number of males and females was in a 1:1 proportion (Fig. 1b). At site $\mathrm{A}$, females were predominant $\left(\chi^{2}=10.40 ; \mathrm{p}<\right.$ 0.0001 ; d.f. $=1)$ in relation to the number of males. At site B females and males occurred in the same proportion $\left(\chi^{2}=1.80 ; p=0.18 ;\right.$ d.f. $\left.=1\right)$.

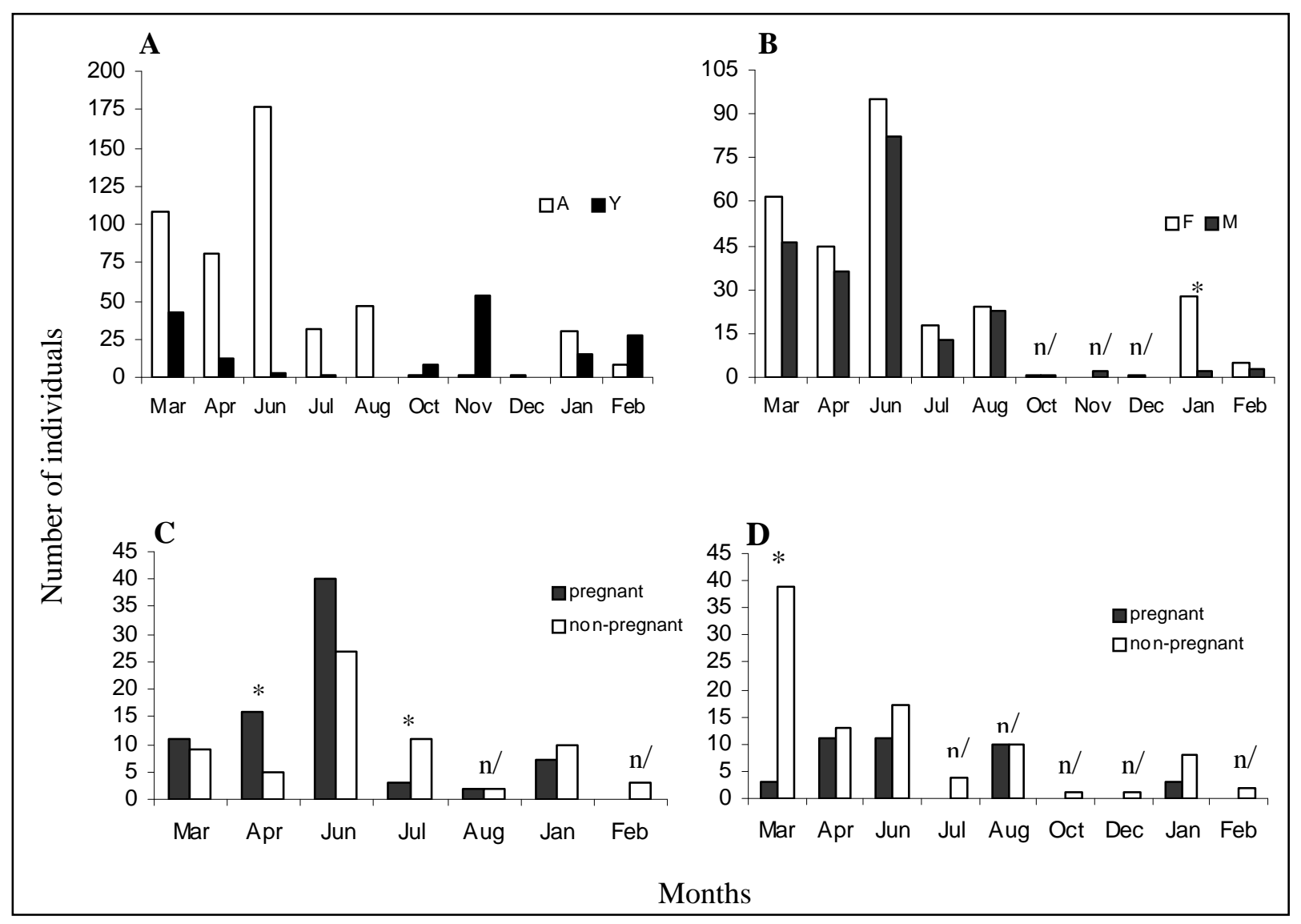

Figure 1 - 1A: Monthly distribution of the occurrence of young and adults of Phalloceros caudimaculatus. 1B: Monthly distribution of females and males of Phalloceros cadimaculatus. 1C: Monthly occurrence of pregnant and non-pregnant females of Phalloceros caudimaculatus at sampling site A. 1D: Monthly occurrence of pregnant and non-pregnant females of Phalloceros caudimaculatus at sampling site B. (*) $\mathrm{x}^{2}$ significant $\alpha=0.05 ; \mathrm{n} /=$ calculation $\mathrm{x}^{2}$ impossible.

When the number of pregnant and non-pregnant females of the two sampling sites were compared, site A showed no significant difference $\left(\chi^{2}=0.99\right.$; $\mathrm{p}=0.32$; d.f. $=1)$. At site $\mathrm{B}$, non-pregnant females were more frequent $\left(\chi^{2}=25.24 ; \mathrm{p}<0.0001\right.$; d.f. $\left.=1\right)$. When the pregnant female frequencies of the two sampling sites were compared, site A showed a higher predominance than site $\mathrm{B}\left(\chi^{2}=14.68 ; \mathrm{p}=\right.$ 0.0001 ; d.f. $=1)$. At site $B$, there was a predominance of non-pregnant females $\left(\chi^{2}=4.86\right.$; $\mathrm{p}=0.03$; d.f. $=1)$. In regard to the monthly occurrence of pregnant and non-pregnant females, at site A (Fig. 1c), there was a significant difference in April $\left(\chi^{2}=6.06 ; \mathrm{p}=0.01\right.$; d.f. $\left.=1\right)$ and July $\left(\chi^{2}=4.86 ; p=0.03 ;\right.$ d.f. $\left.=1\right)$. At site B (Fig. $1 \mathrm{~d})$, a significant difference was observed only in $\operatorname{March}\left(\chi^{2}=36.6 ; p=0.0001 ;\right.$ d.f. $\left.=1\right)$.

\section{DISCUSSION}

To analyze the length-weight relationship, this study made use of $P$. caudimaculatus ranging from 9.0 to $47.9 \mathrm{~mm}$ in total length and from 0.0094 to $1.577 \mathrm{~g}$ in total weight. It was noticed that both for males and females, the relationship between total 
length and total weight was isometric. The same relationship was found by Braga (1986), Barbieri and Verani (1987) and Agostinho et al. (1990). The lines obtained in the length-weight relationship for females and males taken separately did not fit wholly within the confidence interval of the line obtained for the data of the sexes taken together. Thus, males and females presented a differentiated individual growth pattern. This may be attributed to a variation in gonad and stomach weights, which must certainly be higher in bigger individuals (Basile-Martins et al., 1978; Papageorgiou, 1970). Gonads represented up to $15 \%$ of the fish weight, while the stomach up to $30 \%$ (Nikolsky, 1963).

The data obtained for the sampling period indicated that the 21.0-23.9 $\mathrm{mm}$ class was predominant. Females were significantly more predominant in the whole sample and more frequent in all length classes, except for the 21.0$23.9 \mathrm{~mm}$ class. Henn (1916) reported the predominance of females in collections of poeciliids. Some authors suggested that the selective predation might alter the sexual proportion by reducing the percentage of males (Krumholz, 1948), or of females (Britton and Moser, 1982). Aranha and Caramaschi (1999) suggest that the sexual proportion may be influenced also by differences in growth and mortality rates.

In the present study, the widest length amplitude and the largest average and maximum sizes were observed in females. Takeuti et al. (1999) referred to the large somatic size of females as an advantage to the individual fecundity and to the population as a whole. Menezes et al. (1998) found significant predominance of Harta loricariformis females in the months with higher reproductive intensity. Aranha and Caramaschi (1999) also found the predominance of females in their studies on Cyprinodontiformes in a brook in the southeast of Brazil.

In the present study, young individuals were detected in almost every sampling month, except May, August, September and December. It has to be mentioned that despite sampling efforts, no $P$. caudimaculatus were collected in May and September; these months had the highest rainfall averages, according to the records by SANEPAR Guarapuava. Aranha and Caramaschi (1999) have shown that heavy rains were followed by a reduction in the relative abundance and alterations in the constancy of species on stretches of the river.
The number of young decreased from March to August; it increased then and reached its maximum in November, to fall sharply to zero in December; occurrence peaks were registered in November and March. There were pregnant females in March, April, July, August and January, but mostly in July and April. In the studies by Aranha and Caramaschi (1999), was observed a tendency towards seasonality in the occurrence of pregnant females of $P$. caudimaculatus, predominant from August to September, from October to November, from December to January, and from April to May. Isaac-Hahum and Vazzoler (1983) mentioned that environmental factors would have some effect on the cycle's physiology, defining for every region the period of egg production and spawning. In areas where plankton production (or source of food) was seasonal, spawning want occur so that the hatching coincided with the period of greater food availability. According to Thibault and Schulz (1978), internal fertilization might allow, among other things, variations in the interval between reproductive periods and in the gestation period.

The occurrence of pregnant females and young showed a tendency towards seasonality, since results were significant. However, the species had a lengthy reproductive period, which seemed to be the most evident feature. Kramer (1978) reported that fishes from tropical habitats tended to have lengthy reproductive periods. Menezes and Caramaschi (1994) verified these lengthy reproductive periods for species of coastal rivers, and they attributed this strategy to a biological response to unstable environments, where the continuous recruitment individuals would constitute a means to restore the population structure.

At sampling site A, a higher occurrence of pregnant females and young was observed. Sampling site A was characterized by the presence of abundant aquatic and marginal vegetation and of stagnant waters, almost free from motion when compared to sampling site B. Aranha and Caramaschi (1997), studying populations of Cyprinodontiformes in the Ubatiba River (MaricáRJ), reported that individuals of $P$. caudimaculatus generally dwelled on backwaters protected by vegetation, and that when the current flow was more than $0.5 \mathrm{~m} / \mathrm{s}$, they avoided the central course and were found in vegetated and/or marginal stretches. During flood periods, when the current was faster, the abundance of this species decreased 
by the middle of the river and increased in lentic environments.

\section{RESUMO}

A estrutura populacional de Phalloceros caudimaculatus foi estudada em um riacho (pontos A e B) existente no CEDETEG - Guarapuava/PR. Para $P$. caudimaculatus foram encontradas 14 classes de comprimento com amplitude de $3,0 \mathrm{~mm}$. A maior amplitude de comprimento e os maiores tamanhos médios e máximos foram observados nas fêmeas. As fêmeas foram significativamente predominantes na amostra total e mais abundantes em todas as classes de comprimento. Pela proporção sexual pode-se detectar que o número de fêmeas é superior ao de machos a maior parte do ano. Os picos de ocorrência de jovens foram registrados nos meses de novembro e março. As fêmeas grávidas estiveram presentes nos bimestres de março-abril, julho-agosto e no mês de janeiro, caracterizando a época reprodutiva. No ponto de coleta A foi observado uma maior ocorrência de fêmeas grávidas e de jovens.

\section{REFERENCES}

Agostinho, A. A. (1985), Estrutura da população, idade e crescimento de Rhynelepis abtuse (Osteichthys, Loricariidae) do Rio Paranapanema, Pr. Tese de Doutorado. UFSCar- Universidade Federal de São Carlos, São Carlos, SP. 73p.

Agostinho, A. A.; Barbieri, G.; Verani, J. R. and Hahn, N. S. (1990), Variação do fator de condição e do índice hepatossomático e suas relações com o ciclo reprodutivo em Rhinelepis aspera (Agassis, 1829) (Osteichthyes, Loricariidae) no rio Paranapanema, Porecatu, PR. Cien. Cult., 24 : (9), 711-714.

Agostinho, A. A.; Vazzoller, A.E.A.M.; Gomes, C. L. and Okada, E. K. (1993), Estratificacion espacial y comportamiento de Prochilodus scrofa em distintas fases del ciclo de vida, em la planície de inundación del alto Rio Paraná y embalse de Itaipu, Paraná, Brasil. Rev. Hydrobiol. Trop., 26 : (1), 79-90.

Aranha, J. M. R. and Caramaschi, E. P. (1997), Distribuição longitudinal e ocupação espacial de quatro espécies de Cyprinodontiformes no Rio Ubatiba, Marica, RJ, Brasil. Acta Biol. Par., 26 : $(1,2,3,4), 125-140$.
Aranha, J. M. R. and Caramaschi, E. P. (1999), Estrutura populacional, aspectos da reprodução e alimentação dos Cyprinodontiformes (Osteichthyes) de um riacho do sudeste do Brasil. Rev. Bras. Zool., 16 : (1), 637-651.

Aranha, J. M. R.; Takeuti, D. F. and Yoshimura, T. M. (1998), Habitat use and food partioning of the fishes in a coastal stream of Atlantic Forest, Brazil. Rev. Biol. Trop., 46 : (4), 951-959.

Arnold, A. (1989), Der Scheckenkarpfling, ein selten gewordener Lebendgebarender. Aq. Ter. Z., 42, 532 533.

Barbieri, G. and Verani, J. R. (1987), O fator de condição como indicador do período de desova em Hypostomus aff. Plecostomus (Osteichthyes, Loricariidade), na represa do Monjolinho (São Carlos, SP). Cien. Cult., 39 : (7), 665-658.

Barros, F. L. R. (1995), Estudo da diferenciação morfológica e variações do padrão de colorido de populações de Phalloceros caudimaculatus (Hensel, 1868) (Cyprinodontiformes: Poeciliidae: Cnesterodontini). Dissertação de Mestrado, Universidade Federal da Paraíba. 92p.

Basile-Martins, M. A.; Cipóli, M. N. and Godinho, H. M. (1978), Comportamento e alimentação do mandi Pimelodus maculatus Lacépède, 1803 (Osteichthyes, Pimelodidae) de trechos dos rios Jaguari e Piracicaba, São Paulo - Brasil. Bolm. Inst. Pesca, 13 : (1), 17-29.

Bohlke, J. E.; Weitzmann, S. H. and Menezes, N. A. (1978), Estado atual da sistemática de peixes de água doce da América do Sul. Acta Amazonica, 8 : (4), 677-857.

Braga, F.M.S. (1986), Estudo entre fator de condição e relação comprimento/peso para alguns peixes marinhos. Ver. Bras. Biol., 46 : (2), 339-346.

Britton, R. H. and Moser, M. E. (1982), Size specific predation by herons and effect on the sex-ratio of natural populations of the mosquito fish Gambusia affinis Baird and Girard. Oecologia, 53, 146-151.

Dellome Filho, J. (1992), Simuliofauna do rio Marumbi, Morretes, Paraná, Brasil. II. Substratos naturais e artificiais dos imaturos e fauna associada (Diptera, Simuliidae). Acta Biol. Par., 21 : (1,2,3,4), 77-88.

Eigenmann, C. H. (1894), Notes on some South American fishes. Ann. New York Acad. Sci. 7, 625637.

Eigenmann, C. H. (1907), The poeciliid fishes of Rio Grande do Sul and the la Plata basin. Proc. U.S. Nati. Mus. 32 : (1532), 425-433.

Fugi, R. F. and Hahn, N. S. (1991), Espectro alimentar e relações morfológicas com o aparelho digestivo de três espécies de peixes comedores de fundo no rio Paraná, Brasil. Rev. Bras. Biol, 51 : (4), 873-879.

Gealh-Escobar, A. M. N. (1991), Aspectos da biologia e da estrutura da comunidade de peixes da represa Alagados, Ponta Grossa, Pr. Dissertação de Mestrado. Universidade Federal do Paraná, Curitiba, Paraná. $195 \mathrm{p}$. 
Góes De Moraes, M. F. P. (1995), Estudo do tubo digestivo e do hábito alimentar de Hoplias malabaricus, Geophagus brasiliensis e Prochilodus lineatus (Osteichtys, Teleostei) da Lagoa Dourada, Ponta Grossa, Paraná. Dissertação de Mestrado. Universidade Federal do Paraná. Curitiba.

Grando Jr., E. S. (1999), Riqueza e distribuição geográfica de siluriformes (Pisces, Ostariophusy) das Bacias Hidrográficas de Paranaguá e Guaratuba no estado do Paraná. Dissertação de Mestrado. Universidade Federal do Paraná. Curitiba.

Grando, G. C. (2000), Alimentação e reprodução de Pimelodella transitoria Ribeiro, 1905 (Siluriformes, Pimelodidae) no Rio Pai Paulo, município de Guaratuba-PR. Dissertação de mestrado. Universidade Federal do Paraná, Curitiba, Paraná.

Henn, A. W. (1916), On various South American poeciliid fishes. Ann. Carn. Mus. 10 : (1-2),124-126.

Hensel, R. (1868), Beitrage zur kenntnis der wirbelthiere Sudbrasiliens. (Contribution to knowledge of the vertebrates of southern Brazil). Arch. F. Naturg., 34, 356-375.

Ihering, R. V. (1931), Cyprinodontiformes brasileiros (Peixes "Guaru"), sistemática e informações biológicas. Arch. Inst. Biol. 4, 243-280.

Isaac-Nahum, V. J. and Vazzoler, A.E.A.M. (1983), Biologia reprodutiva de Micropogonias furnieri (Desmarest, 1923) (Teleostei, Scienidae). 1. Fator de condição como indicador do período de desova. Bolm. Inst. Oceanogr., 32 : (1), 63-69.

Kramer, D. L. (1978), Reproductive seasonality in the fishes of a tropical stream. Ecology, 59 (5), 976-985.

Krumholz, L. A. (1948), Reproduction in the western mosquito-fish Gambusia affinis (Baird and Giard), and its use in mosquito control. Ecol. Monog., 18, 143.

Lulling, K. H. (1976), Der untere jaquaripi vor der Mondung in den Atlantik (Gezeitenzone) und seine charakteristischen fische (Salvador, Bahia. Ostrabasilien). Anz. Jena, 197, 335-355.

Menezes, N. A. (1972), Distribuição e origem da fauna de peixes de água doce das grandes bacias fluviais do Brasil. In: Poluição e Piscicultura, Comissão Internacional da Bacia Paraná/Uruguai. Faculdade de Saúde Pública USP e Instituto de Pesca, São Paulo. 79-108p.

Menezes, N. A. (1994), Importância da conservação da ictiofauna dos ecossistemas aquáticos brasileiros. In: Comitê Coordenador das Atividades de Meio Ambiente do Setor Elétrico - COMASE, ELETROBRÁS, Curitiba. Seminário sobre a fauna aquática e o setor elétrico brasileiro, reuniões temáticas preparatórias: caderno 3-conservação.
Menezes, M. S., Aranha, J. M. R. and Caramaschi, E. P. (1998), Ocorrência e aspectos da biologia reprodutiva Hartia loricariformis (Loricariinae) no trecho inferior do rio Paraíba do Sul (Rio de Janeiro, Brasil). Acta Biol. Par., 27 : (1,2,34,), 15-26.

Menezes, M. S. and Caramaschi, E. P. (1994), Características reprodutivas de Hypostomus grupo $H$. punctatus (Osteichthyes, Siluriformes) no rio Ubatiba, Marica, RJ. Rev. Brás. Zool., 54 : (3), 503-513.

Nikolski, M.E. (1963), The ecology of fishes. London: Academic Press. 352pp.

Papageorgiou, N. K. (1979), The lenght weight relationship age, growth and reproduction of the roach Rutilus rutilus (L.) in Lake Volvi. J. Fish Biol., 14 : (6), 529-538.

Rosen, D. E. and Bailey, R. M. (1963), The poeciliid fishes (Cypirnodontiformes), their struture, zoogeography and systematics. Bull. Amer. Mus. Hist, 126, 1-176.

Sabino, J. and Castro, R. M. C. (1990), Alimentação, período de atividade e distribuição espacial dos peixes de um riacho da floresta Atlântica (Sudeste do Brasil). Rev. Brasil. Biol., 50 : (1), 23-36.

Silva, J. X. and Souza, M. J. L. (1987), Análise ambiental. Rio de Janeiro: Abeu Ed. Associada. 196pp.

Takeuti, D. F., Verani, J. R., Aranha, J. M. R. and Menezes, M. S. (1999), Population structure and condition factor of Pseudotothyris obtusa (Hypoptopomatinae) from three coastal streams in southern Brazil. Braz. Arch. Biol. and Technol., 42 : (92), 379-403.

Thibault, R. E. and Schultz, R. J. (1978), Reproductive adaptations among viviparous fishes (Cyprinodontiformes:Poeciliidae). Evolution, 32 : (2), 320-333.

Wosiacki, W. B. (1990), Sobre a ictiofauna registrada na Reserva Florestal de Guaricana (Paraná). Arq. Biol. Tecnol., 33 : (3), 527-534.

Wosiacki, W. V. and Cury, M. R. (1990), Inventário preliminar da ictiofauna da área de especial interesse turístico do Marumbi (Paraná) com comentários ictiogeográficos. Arq. Biol. Tecnol., 33 : (2), 379-392. 
PÁGINA

EM

BRANCO 